\title{
Phage Lytic Protein LysRODI Prevents Staphylococcal Mastitis in Mice
}

\author{
Diana Gutiérrez ${ }^{1 \dagger}$, Victoria Garrido², Lucía Fernández', Silvia Portilla', Ana Rodríguez', \\ María Jesús Grilló ${ }^{2}$ and Pilar García ${ }^{\text {1* }}$
}

${ }^{1}$ DairySafe Group, Departamento de Tecnología y Biotecnología de Productos Lácteos, Instituto de Productos Lácteos de Asturias (IPLA-CSIC), Villaviciosa, Spain, ${ }^{2}$ Departamento de Sanidad Animal, Instituto de Agrobiotecnología, CSIC-Gobierno de Navarra, Mutilva, Spain

Phage lytic proteins are promising antimicrobials that could complement conventional antibiotics and help to combat multi-drug resistant bacteria that cause important human and animal infections. Here, we report the characterization of endolysin LysRODI (encoded by staphylophage philPLA-RODI) and its application as a prophylactic mastitis treatment. The main properties of LysRODI were compared with those of endolysin LysA72 (encoded by staphylophage philPLA35) and the chimeric protein CHAPSH3b (derived from the virion-associated peptidoglycan hydrolase HydH5 and lysostaphin). Time-kill experiments performed with Staphylococcus aureus and Staphylococcus epidermidis demonstrated that the killing rate of LysRODI and CHAPSH3b is higher than that of LysA72 $(0.1 \mu \mathrm{M}$ protein removed $10^{7} \mathrm{CFU} / \mathrm{ml}$ of $\mathrm{S}$. aureus in $30 \mathrm{~min}$ ). Of note, all proteins failed to select resistant mutants as bacterial exposure to sub-lethal concentrations of the proteins did not alter the MIC values. Additionally, LysRODI and CHAPSH3b were non-toxic in a zebrafish embryo model at concentrations near the MIC $(0.5$ and $0.7 \mu \mathrm{M}$, respectively). Moreover, these two proteins significantly reduced mortality in a zebrafish model of systemic infection. In contrast to LysRODI, the efficacy of CHAPSH3b was dosedependent in zebrafish, requiring higher-dose treatments to achieve the maximum survival rate. For this reason, LysRODI was selected for further analysis in mice, demonstrating great efficacy to prevent mammary infections by $S$. aureus and S. epidermidis. Our findings strongly support the use of phage lytic proteins as a new strategy to prevent staphylococcal mastitis.

Keywords: endolysin, antimicrobial activity, Staphylococcus, mastitis, bacteriophages

\section{INTRODUCTION}

Multidrug resistant (MDR) pathogenic bacteria cause nowadays more than 700,000 deaths per year in the world, affecting developing and developed countries, rural and urban areas, hospitals, farms and communities ${ }^{1}$. Since the emergence of MDR pathogenic bacteria is an urgent global risk that remains unsolved, it is imperative to strengthen antimicrobial use regulations and

${ }^{1}$ https://www.who.int/news-room/fact-sheets/detail/antimicrobial-resistance 
foster innovative research on new ways to combat bacteria. WHO has developed a global priority list of MDR pathogenic bacteria, in which Staphylococcus aureus is considered as Priority 2 (High), with the aim of helping to prioritize research and development of new antibiotic treatments ${ }^{2}$.

S. aureus is along with Staphylococcus epidermidis an important cause of bovine mastitis, the most widespread disease in dairy cattle (Nyman et al., 2018). These infections are very difficult to cure due to the ability of staphylococci (and $S$. aureus, in particular) to adhere and proliferate on animal tissues forming a biofilm that, together with somatic cells, clog milk canals within the mammary gland. This leads to an insufficient penetration of the antibiotic in the mammary gland when infused into the udder. Moreover, the increasing rate of MDR strains; and the ability of $S$. aureus to persist within mammary gland epithelial cells in a low metabolic state, thereby evading antibiotic treatment, is the main cause of recurrent and chronic infections associated to mastitis infections (Gomes et al., 2016). Apart from the derived economic losses, mastitis is also the main cause of antibiotic use in the dairy industry (Hogeveen et al., 2011). However, the increasing generation of MDR pathogenic bacteria is promoting a more restrictive use of antimicrobials in animal husbandry that is totally banned in some countries as prophylactic in animal feed (European Commission, 2017).

Over the last years, the study of bacteriophage-encoded lytic proteins, including endolysins and virion-associated peptidoglycan hydrolases (VAPGHs), for the treatment of infectious diseases has attracted great interest (Fischetti, 2010; Rodriguez-Rubio et al., 2016a). These enzymes kill bacteria through peptidoglycan degradation followed by osmotic lysis. A pipeline portfolio recently published in The Lancet Infectious Diseases, highlighted endolysin-based antimicrobials as the compounds with the greatest potential to be used as novel therapeutics (Czaplewski et al., 2016). Indeed, there is evidence that many phage lytic proteins (enzybiotics) are effective in animal models of infection (Schmelcher et al., 2015a) and also clinical phase I trials have been completed without the observation of adverse effects (Jun et al., 2017). Phage lytic proteins have also been proposed as potential disinfectants for the food industry (Gutierrez et al., 2016) due to their rapid bactericidal action and biodegradability.

Most endolysins from phages infecting Gram-positive bacteria have a modular structure (Oliveira et al., 2013), which facilitates protein engineering via domain shuffling to obtain new chimeric proteins with improved lytic activity (Blazquez et al., 2016). Regarding S. aureus, several published reports have shown the effectiveness of phage lytic proteins as therapeutics (Schuch et al., 2014), biopreservatives (Chang et al., 2017) and disinfectants (Gutiérrez et al., 2014).

In our previous work, we identified and characterized four S. aureus infecting phages, the siphophages phiIPLA88 and phiIPLA35 and the myophages phiIPLA-RODI and phiIPLA-C1C

${ }^{2}$ http://www.who.int/medicines/publications/global-priority-list-antibioticresistant-bacteria/en/
(García et al., 2009; Gutiérrez et al., 2015). Two phage lytic proteins were identified in phage phiIPLA88, the endolysin LysH5 and the VAPGH protein HydH5 (Obeso et al., 2008; Rodríguez et al., 2011). Endolysin LysH5 has showed lytic activity against $S$. aureus in pasteurized milk (Obeso et al., 2008; García et al., 2010) and also against staphylococcal biofilms (Gutiérrez et al., 2014). Moreover, chimeric proteins derived from $\mathrm{HydH} 5$ and the bacteriocin lysostaphin were also obtained by combination of domains. The chimeric protein $\mathrm{CHAPSH} 3 \mathrm{~b}$ (CHAP domain from HydH5 and the SH3b CBD from lysostaphin) showed the highest specific activity (RodriguezRubio et al., 2012). Subinhibitory doses of this chimeric protein can prevent $S$. aureus biofilm formation through the downregulation of autolysin-encoding genes (Fernandez et al., 2017). Moreover, two novel endolysins from phages phiIPLA35 and phiIPLA-RODI (orf60 and orf57, respectively) were identified (García et al., 2009; Gutiérrez et al., 2015).

In this work, we have compared the main properties, in terms of enzymatic activity, of three phage lytic proteins; the two novel endolysins LysRODI and LysA72, and the chimeric protein CHAPSH3b. In a first step, a selection of the highest active proteins was performed based on in vitro experiments. Then, they were further validated in vivo using a systemic infection model in zebrafish. Finally, the ability of the most active protein (i.e. LysRODI) to prevent staphylococcal-induced mastitis was analyzed in lactating mice.

\section{MATERIALS AND METHODS}

\section{Bacterial Strains and Culture Conditions}

The staphylococcal strains used in this study (Table 1) were grown in tryptic soy broth (TSB; Difco, Franklin Lakes, NJ) at $37^{\circ} \mathrm{C}$ with shaking at $250 \mathrm{rpm}$ or on TSB plates containing $2 \%$ (wt/vol) bacteriological agar (TSA). Escherichia coli BL21 (DE3) was used for protein expression grown at $37^{\circ} \mathrm{C}$ with shaking in LB medium ( $1 \%$ tryptone, $0.5 \%$ yeast extract, $1 \%$ $\mathrm{NaCl})$ or on plates of LB supplemented with $2 \%(w / v)$ agar. For proper selection of the clones, $100 \mu \mathrm{g} / \mathrm{ml}$ of ampicillin (Sigma Aldrich, Madrid, Spain) were added.

\section{Structural and Functional Bioinformatics Analysis of the Endolysins}

The protein sequences of LysRODI (Genbank accession number YP_009195893.1) and LysA72 (Genbank accession number YP_002332423.1) were analyzed using BLASTP (Altschul et al., 1990) and HMMER v3.2.1 ${ }^{3}$ in order to identify the enzymatic activity domains. The protein sequences were compared with those from staphylococcal phage endolysins available in public databases (Pubmed, accessed January 2019) by CLUSTAL W alignment using Geneious 7.1.34. The 3D structure of the proteins was predicted using the web-based server Phyre2 (Kelley et al., 2015).

${ }^{3}$ hmmer.org

${ }^{4}$ https://www.geneious.com 
TABLE 1 | Staphylococcus spp. strains used in this work.

\begin{tabular}{|c|c|c|c|c|c|c|}
\hline \multirow[t]{2}{*}{ Specie } & \multirow[t]{2}{*}{ Strain } & \multirow[t]{2}{*}{ Origin } & \multirow[t]{2}{*}{ Reference } & \multicolumn{3}{|c|}{$\operatorname{MIC}(\mu \mathrm{M})^{\mathrm{a}}$} \\
\hline & & & & LysRODI & LysA72 & CHAPSH3b \\
\hline \multirow[t]{6}{*}{ S. aureus } & Sa9 & Milk from cows with clinical mastitis & García et al., 2009 & 0.57 & 1.47 & 0.33 \\
\hline & Sa10 & & & 0.57 & 1.47 & 0.33 \\
\hline & 15,981 & Human clinical isolate. Strong biofilm former & Valle et al., 2003 & 1.15 & 1.47 & 0.66 \\
\hline & ATCC $^{\circledR} 25923^{\text {TM }}$ & $\begin{array}{l}\text { Human clinical isolate with the designation Seattle } \\
1945 \text { that is used as a standard laboratory testing } \\
\text { control strain }\end{array}$ & ATCC strain & 0.57 & 1.47 & 0.66 \\
\hline & 7,829 & Pig skin. Methicillin-resistant S. aureus (MRSA) & Unpublished & 1.15 & 5.88 & 0.66 \\
\hline & Staph. 15 & $\begin{array}{l}\text { Human clinical isolate. Methicillin-resistant } \\
\text { S. aureus (MRSA) }\end{array}$ & Unpublished & 1.15 & 5.88 & 1.33 \\
\hline \multirow[t]{4}{*}{ S. epidermidis } & F12 & Milk from woman with mastitis & Delgado et al., 2009 & 1.15 & $>23.52$ & 0.33 \\
\hline & B & & & 0.57 & $>23.52$ & 0.33 \\
\hline & DG2n & & & 1.15 & $>23.52$ & 1.33 \\
\hline & LV5RB3 & Milk from healthy woman & Delgado et al., 2009 & 2.29 & $>23.52$ & 0.33 \\
\hline S. sciuri & 101 & Milk from healthy woman & Martín et al., 2012 & 4.59 & $>23.52$ & 0.33 \\
\hline S. hominis & ZL31-13 & & & 1.15 & $>23.52$ & 0.33 \\
\hline S. pasteuri & ZL16-6 & & & 2.29 & $>23.52$ & 0.66 \\
\hline S. xylosus & ZL61-2 & & & 1.15 & $>23.52$ & 0.66 \\
\hline S. saprophyticus & ZL112-15 & & & 0.15 & $>23.52$ & 0.66 \\
\hline S. arlattae & ZL114-5 & & & 1.14 & $>23.52$ & 0.66 \\
\hline S. haemolyticus & ZL89-3 & & & 0.57 & 1.47 & 0.33 \\
\hline S. gallinarum & ZL90-5 & & & 1.14 & $>23.52$ & 0.33 \\
\hline S. kloosii & ZL74-2 & & & 1.14 & $>23.52$ & 0.66 \\
\hline
\end{tabular}

aMinimum inhibitory concentration (MIC) expressed as $\mu \mathrm{M}$.

Data represent the mode of three independent biological repeats.

\section{Plasmid Construction and DNA Manipulation}

The genes encoding LysRODI (Gene ID: 26623165) and LysA72 (GeneID: 7057022) were optimized based on E. coli codon usage by the OptimumGene ${ }^{\mathrm{TM}}$ codon optimization technology ${ }^{5}$. Additionally, NdeI and XhoI restriction sites were added at the $5^{\prime}$ and $3^{\prime}$ end, respectively. The optimized sequences were synthetized and cloned into the pET21a vector by GenScript (Township, NJ, USA). This vector introduces a C-terminal $\mathrm{His}_{6}$-tag and carries an ampicillin resistance gene. The pET21a vector containing the gene was then transformed into E. coli BL21 (DE3). The clones overexpressing CHAPSH3b were obtained in a previous study (Rodriguez-Rubio et al., 2012).

\section{Protein Overexpression, Purification and Endotoxin Removal}

Protein expression was performed by induction with $1 \mathrm{mM}$ IPTG (isopropyl- $B-D$-thiogalactopyranoside) and incubation at $16^{\circ} \mathrm{C}, 16 \mathrm{~h}$, as previously described (Gutierrez et al., 2015). For control purposes for in vivo experiments, E. coli BL21 cells transformed with the empty pET21a vector were used and purified as the rest of the proteins (MOCK control). After protein expression, cells were centrifuged $\left(10,000 \mathrm{rpm}, 4^{\circ} \mathrm{C}\right.$, $15 \mathrm{~min}$ ) and suspended in $10 \mathrm{ml}$ of lysis buffer $(20 \mathrm{mM}$ $\mathrm{NaH}_{2} \mathrm{PO}_{4}, 500 \mathrm{mM} \mathrm{NaCl}, 10 \mathrm{mM}$ imidazole, $\mathrm{pH}$ 7.4). Pellets were freeze/thawed three times at $-80^{\circ} \mathrm{C}$. Sonication was carried out afterwards $(15 \times 5 \mathrm{~s}$ pulses with $15 \mathrm{~s}$ recovery

$\overline{{ }^{5} \text { https://www.genscript.com/codon-opt.html }}$ on ice; $40 \%$ of amplitude). Then, the suspension was centrifuged at $10,000 \mathrm{rpm}, 4^{\circ} \mathrm{C}, 30 \mathrm{~min}$. Proteins were purified by immobilized metal ion affinity chromatography using nickel-NTA Superflow resin columns (Qiagen, Valencia, CA, USA) following supplier's recommendations. Briefly, $1 \mathrm{ml}$ of resin was added to $10 \mathrm{ml}$ of protein lysate. This mixture was incubated at $4^{\circ} \mathrm{C}$ for $16 \mathrm{~h}$ with slow shaking and then loaded onto $5 \mathrm{ml}$ columns (BioRad, Hercules, CA, USA). For purification and endotoxin removal, a protocol described previously was performed (Reichelt et al., 2006). When using the protein for in vivo experiments (endotoxin-free), columns were washed with $50 \mathrm{ml}$ of lysis buffer supplemented with $0.1 \%$ Triton X-114. Afterwards, columns were washed with $20 \mathrm{ml}$ of lysis buffer and $50 \mathrm{ml}$ of wash buffer $\left(20 \mathrm{mM} \mathrm{NaH}_{2} \mathrm{PO}_{4}, 500 \mathrm{mM} \mathrm{NaCl}, 20 \mathrm{mM}\right.$ imidazole, $\mathrm{pH}$ 7.4). For all other experiments, Triton X-114 was omitted and columns were washed with $30 \mathrm{ml}$ of lysis buffer and $50 \mathrm{ml}$ of wash buffer instead. Finally, the purified proteins were recovered with $1.5 \mathrm{ml}$ of elution buffer $(20 \mathrm{mM}$ $\mathrm{NaH}_{2} \mathrm{PO}_{4}, 500 \mathrm{mM} \mathrm{NaCl}, 250 \mathrm{mM}$ imidazole, $\mathrm{pH}$ 7.4) and subsequently stored at $-80^{\circ} \mathrm{C}$ in the presence of $30 \%$ glycerol to prevent precipitation.

Protein purity was evaluated in $12 \%$ (vol/wt) SDS-PAGE run at $150 \mathrm{~V}$ using Criterion precast gels (BioRad), and further revealed via conventional Coomassie staining. Protein concentration was quantified by the Quick Start Bradford Protein assay (BioRad).

Prior to the experiments, the buffer was exchanged to $50 \mathrm{mM}$ sodium phosphate $(\mathrm{NaPi})$ buffer $(\mathrm{pH}=7.4)$ using “Zeba ${ }^{\mathrm{TM}}$ Spin Desalting Columns, 7K MWCO, 5 ml” (Thermo Fisher Scientific, Madrid, Spain) following the supplier's 
recommendations. Finally, proteins were filtered $(0.45 \mu \mathrm{m}$ PES membrane filters; VWR, Spain).

\section{Quantification of Specific Lytic Activity}

Turbidity reduction assay was performed as previously described (Obeso et al., 2008) using S. aureus Sa9 cells suspended in $\mathrm{NaPi}$ buffer $(50 \mathrm{mM} ; \mathrm{pH}=7.4)$ and treated with two-fold dilutions of the purified proteins $(0.02-50 \mu \mathrm{M})$. Results were expressed as specific lytic activity $\left(\Delta \mathrm{OD}_{600} \times \min ^{-1} \times \mu \mathrm{M}^{-1}\right)$ (Donovan et al., 2006). To evaluate the effect of several cations on enzymatic activity, different salts $\left(\mathrm{KCl}, \mathrm{MgCl}_{2}, \mathrm{NaCl}, \mathrm{MnCl}_{2}\right.$, $\mathrm{ZnCl}_{2}, \mathrm{CaCl}_{2}$ ) were added at a final concentration of $10 \mathrm{mM}$. The effect of temperature in protein activity was evaluated by incubating an aliquot of the protein for $30 \mathrm{~min}$ at different temperatures $\left(40-90^{\circ} \mathrm{C}\right)$, followed by a turbidity reduction assay. In addition, the effect of $\mathrm{pH}$ on activity was tested by diluting (1:100) the proteins into Britton-Robinson buffer (150 mM $\mathrm{KCl}, 10 \mathrm{mM} \mathrm{KH}_{2} \mathrm{PO}_{4}, 10 \mathrm{mM}$ sodium citrate, $10 \mathrm{mM} \mathrm{H}_{3} \mathrm{BO}_{3}$ ) adjusted to $\mathrm{pH} 3$ to 11 . In this case, the turbidity reduction assay was carried out with the $S$. aureus Sa9 cells also suspended in the Britton-Robinson buffer. All experiments were performed in triplicate.

\section{Minimum Inhibitory Concentration (MIC) of Phage Lytic Proteins}

The MIC of the proteins was determined in triplicate by the conventional broth microdilution technique in TSB (CLSI, 2015). The MIC was defined as the lowest protein concentration that inhibited visible bacterial growth after $24 \mathrm{~h}$ of incubation at $37^{\circ} \mathrm{C}$ and expressed as the mode of three replicates.

\section{Time-Killing Assays}

The antibacterial activity was performed as previously described (Rodriguez-Rubio et al., 2016b) using as substrate $S$. aureus Sa9 diluted in TSB $\left(\sim 10^{7} \mathrm{CFU} / \mathrm{ml}\right)$ and $0.1 \mu \mathrm{M}$ of each protein. As a control for bacterial growth, $50 \mathrm{mM}$ sodium phosphate $(\mathrm{NaPi})$ buffer $(\mathrm{pH}=7.4)$ were added instead of the proteins. The cultures were incubated at $37^{\circ} \mathrm{C}$ with shaking (250 r.p.m) and $50 \mu \mathrm{l}$ of samples were taken at different time points (2-60 min). Reaction was immediately stopped by adding $0.15 \mu \mathrm{g}$ of proteinase $\mathrm{K}$. Bacterial dilutions were then plated onto TSA and incubated at $37^{\circ} \mathrm{C}$ for $16 \mathrm{~h}$. The antibacterial activity of three independent replicates was quantified as the relative inactivation in $\log$ units $\left[\log _{10}\left(N_{0} / N_{\mathrm{i}}\right)\right.$ with $N_{0}$ as the initial number of untreated cells and $\mathrm{N}_{\mathrm{i}}$ as the number of residual cells counted after treatment] (Rodriguez-Rubio et al., 2016b).

\section{Development of Bacterial Resistance to Lytic Proteins}

Resistance development was tested using repeated exposures to protein concentrations according to the minimal inhibitory concentration (MIC) assays (Becker et al., 2016). Two-fold serial dilutions of the proteins $(0.02-50 \mu \mathrm{M})$ were used against $S$. aureus $\mathrm{Sa} 9\left(10^{6} \mathrm{CFU}\right)$ and $S$. epidermidis $\mathrm{F} 12\left(10^{6} \mathrm{CFU}\right)$ grown in a 96 polystyrene microtiter plate at $37^{\circ} \mathrm{C}$ for $16 \mathrm{~h}$. The next day, $100 \mu \mathrm{l}$ of the first well with growth $(0.5 \times$ MIC) were inoculated into $5 \mathrm{ml}$ of TSB and grown to an $\mathrm{OD}_{600}=0.5$. These cultures were used for the next round of MIC exposure. The experiment was repeated for 10 rounds, followed by 5 additional rounds in TSB without the protein in order to allow phenotype reversion. Then MIC assay was further performed to measure the sensitivity to the proteins. Experiments were performed using three independent biological replicates. As a positive control of the experiment, the bacteriocin lysostaphin (Sigma, Missouri, USA), produced by Staphylococcus simulans, was also tested.

\section{Biofilm Assays}

Staphylococcal biofilm formation and removal was performed as previously described using the RTCA technology (Gutiérrez et al., 2016; Gutierrez et al., 2017). Briefly, $100 \mu \mathrm{l}$ of S. aureus 15,981 were diluted in TSBg (TSB supplemented with $0.25 \%$ w/v D-(+)-glucose) and poured into 16 -well E-plates $\left(\sim 10^{6} \mathrm{CFU} /\right.$ well). E-plates were connected to the xCelligence RTCA-DP (ACEA Biosciences Inc., San Diego, CA, USA) holder which measure the impedance signal and represent cell index (CI) values. Biofilm were formed for $8 \mathrm{~h}$ at $37^{\circ} \mathrm{C}$ and then $100 \mu \mathrm{l}$ of LysRODI and LysA72 were added to achieve a concentration gradient (0.14-9.15 $\mu \mathrm{M}$ and $0.21-13.42 \mu \mathrm{M}$, respectively) and incubated for an extra $16 \mathrm{~h}$. Impedance values were further processed using the RTCA software 1.2.1 (ACEA Biosciences Inc.) as described previously (Gutierrez et al., 2017) in order to calculate: (i) the percentage of biofilm removal compared to control values after $16 \mathrm{~h}$ of treatment; (ii) the minimum biofilm eradicating concentration that removes $50 \%$ of the biofilm $\left(\mathrm{MBEC}_{50}\right)$, (iii) the lowest antibiofilm effect (LOABE; lowest concentration needed to observe an antibiofilm effect) and (iv) the specific antibiofilm activity expressed as $\Delta$ baseline normalized $\mathrm{CI} \times \mathrm{min}^{-1} \times \mathrm{mM}^{-1}$. All the experiments were performed in triplicate.

\section{Safety and Efficacy of the Proteins in Zebrafish}

Safety and efficacy of LysRODI and CHAPSH3b were evaluated in two zebrafish models (IKAN Biotech, Navarra, Spain; www. ikanbiotech.com). The experiments and protocols were performed according to the Organization for Economic Cooperation and Development (OECD) following the Standard Guide for Conducting Acute Toxicity Tests (ASTM) and ISO 20776-1:2007 regulations, achieving the Good Laboratory Practices.

Safety was evaluated by the acute toxicity induced in zebrafish embryos by $1 \times$ MIC of the correspondent protein. To do this, eggs were collected after fecundation and kept in a Petri dish containing E3 medium $(5 \mathrm{mM} \mathrm{NaCl}, 0.17 \mathrm{mM} \mathrm{KCl}$, $0.33 \mathrm{mM} \mathrm{CaCl}, 0.33 \mathrm{mM} \mathrm{MgSO}_{4}, 0.0001 \%$ methylene blue) at $34^{\circ} \mathrm{C}$ until the next day. Zebrafish embryos $(n=8)$ were individually placed in 96-well microplates and $100 \mu \mathrm{l}$ of the protein was added $(0.73 \mu \mathrm{M}$ for LysRODI and $0.55 \mu \mathrm{M}$ for CHAPSH3b). As negative and positive controls, $100 \mu \mathrm{l}$ of E3 medium and $100 \mu \mathrm{l}$ of E3 supplemented with $1 \mathrm{mg} / \mathrm{ml}$ paracetamol (Alfa Aesar, VWR) (Bastiaan Vliegenthart et al., 2014) were used, respectively. The plates were incubated at $34^{\circ} \mathrm{C}$ and 
observations were recorded after $72 \mathrm{~h}$. To evaluate the toxicity of the proteins, all embryos were visually inspected (apical parameters, sub-lethal or teratogenic symptoms and mortality). Results are expressed as percentage of surviving embryos. To assess the reproducibility of the model, each experiment $(n=8)$ was performed in triplicate.

To test the lytic efficacy of LysRODI and CHAPSH3b, a systemic model of $S$. aureus infection in adult zebrafish was used. First, zebrafish $(n=18)$ were kept at $34^{\circ} \mathrm{C}$ for $24 \mathrm{~h}$. Fish were then anesthetized with tricaine MS-222 (SigmaAldrich) for $10 \mathrm{~min}$ and, intraperitoneally inoculated with $10 \mu \mathrm{l}$ of a suspension containing $\sim 10^{5} \mathrm{CFU} /$ fish of $S$. aureus ATCC $^{\circledR} 25923^{\mathrm{TM}}$, using a Hamilton syringe with $31 \mathrm{G}$ gauge needles (BD Microlance). After 1-h post-infection, fish were treated with different concentrations $(1 \times$ MIC, $0.5 \times$ MIC or $3 \times$ MIC) of LysRODI or CHAPSH3b, and kept at $34^{\circ} \mathrm{C}$ for $72 \mathrm{~h}$. The number of surviving zebrafish was recorded for $72 \mathrm{~h}$ post-treatment. As control, adult zebrafish $(n=18)$ were infected with the bacteria and inoculated with $0.85 \%$ of sodium chloride solution (Sigma Aldrich). The percentage of cumulative survival zebrafish was represented by the Kaplan-Meier analysis.

\section{Efficacy in a Mouse Model of Mastitis}

Male and female CD1 mice of 20-22 g bodyweight were purchased at Charles River International (France) and accommodated in the animal facilities of the "Instituto de Agrobiotecnología" (registration code ES/31-2016-000002-CRSU-US) with water and food ad libitum. Mice handling and procedures were performed in compliance with the current European and International regulations, following the welfare guidelines and recommendations of the Federations of European Laboratories of Animal Science Associations (FELASA) (Rehbinder et al., 2000) and Animal Research Reporting of in vivo Experiments (ARRIVE) (Kilkenny et al., 2010) and the study was approved by the Comité de Ética, Experimentación Animal y Bioseguridad (CEEAB) of the Public University of Navarra (PI/018-19).

Pregnancies were synchronized by circadian cycle adjustment and introduction of males in the same cage for 3 days. Ten days after delivery, the offspring were removed and the lactating females $(n=7)$ were treated intramammary. For that, mice were intraperitoneally anesthetized with a mixture of ketamine $100 \mathrm{mg} / \mathrm{kg}$ (Imalgene ${ }^{\circledR}$, Merial Laboratorios, S.A) and xylacine $10 \mathrm{mg} / \mathrm{kg}$ (Rompun ${ }^{\circledR}$, Bayer Health Care), and, then, treated in the R4 teat by intramammary administration of $0.1 \mathrm{ml}$ containing $24 \mu \mathrm{g} /$ mouse of LysRODI $(n=7)$ or PBS $(n=4)$ by using a 33 gauge blunt-end needle in a Hamilton syringe (Hamilton). All mice were challenged at 90 min post-treatment, by intramammary inoculation of $5 \times 10^{4} \mathrm{CFU} /$ mouse of $S$. aureus Sa10 or $S$. epidermidis $\mathrm{B}$, and, $18 \mathrm{~h}$ later, the R4-R5 mammary glands were aseptically removed, individually weighed, serially diluted in PBS (1:9) and plated in agar, in order to determine the number of CFU/gland. An additional control group $(n=3)$ was intramammary inoculated with MOCK buffer and challenged with one of the pathogens (i.e. S. epidermidis B) as before. Clinical signs of hyperemia or edema with changes in color, texture or size of the mammary gland were determined by visually inspection after the treatment.

\section{Statistical Analysis}

The SPSS Statistics for Windows V. 22.0 (IBM Corp.) was used for all calculations. The data obtained from the in vitro activity tests (specific lytic activity, time-kill assays, biofilm assays and determination of bacterial resistance) were expressed as the mean \pm standard deviation of three biological replicates. One-way ANOVA followed by the Student-Newman-Keuls (SNK) or Protected Least Significant Differences (PLSD) post-hoc tests, were used to determine differences in protein activity and also in the mouse model of mastitis. On the other hand, the student $\mathrm{t}$-test was used to compare the differences between the treated and untreated bacterial cultures at a level of significance $p<0.05$. Statistical comparison of surviving embryos fish was performed by Chi-square test. The percentage of cumulative survival zebrafish was calculated and plotted by Kaplan-Meier cumulative survival analysis and statistically compared by the Log-Rank test, using the StatView ${ }^{\circledast}$ SAS package (SAS Institute Inc., Version 5).

\section{RESULTS}

\section{New Endolysins LysRODI and LysA72 Were Identified From Phage Genomes}

Two new endolysins encoded by bacteriophages infecting S. aureus (phiIPLA-RODI and phiIPLA35) were identified (LysRODI and LysA72, respectively) (García et al., 2009), (Gutiérrez et al., 2015). Bioinformatics analysis of these proteins revealed that both possess a modular structure composed by two catalytic domains (CHAP and amidase) and one SH3b cell wall binding domain. LysRODI possesses an amidase belonging to the "type 2" family, while LysA72 carries an amidase "type 3" (Supplementary Figure 1). The predicted 3D structure of the proteins using Phyre2 revealed a modular organization of the domains clearly separated by a linker region (Supplementary Figure 1). LysRODI exhibited a high similarity (>98\%) with other endolysins available in public databases, more specifically with those encoded by staphylococcal Myoviridae phages (Supplementary Figure 2A). On the other hand, LysA72 has a high similarity with endolysins encoded by other staphylococcal siphophages (Supplementary Figure 2B).

Following computer analysis, the genes coding for LysRODI $(54.8 \mathrm{kDa})$ and LysA72 $(53.8 \mathrm{kDa})$ were cloned into the expression vector pET21a and overexpressed in E. coli BL21 (DE3). Nevertheless, after the purification process, proteins LysRODI and LysA72 were not completely soluble, and the concentration of purified protein was 0.6 and $0.3 \mathrm{mg} / \mathrm{ml}$, respectively. To improve the purification efficiency, the endolysin-encoding genes were optimized for expression in E. coli. The new constructs resulted in completely soluble proteins with an increased purification yield ( 2.5 and $1.1 \mathrm{mg} / \mathrm{ml}$, respectively). The chimeric 
protein CHAPSH3b (30.4 kDa) was purified as described previously with a yield of $0.9 \mathrm{mg} / \mathrm{ml}$ (Rodriguez-Rubio et al., 2012).

\section{LysRODI Shows a High Lytic Activity Against a Broad Range of Staphylococcal Species}

The minimum inhibitory concentration (MIC) of the three proteins was calculated against a collection of staphylococcal species including strains from different origins (Table 1). It is worth noting that LysA72 was active only against $S$. aureus and S. haemolyticus strains, while LysRODI and CHAPSH3b were able to lyse all the tested staphylococcal species and displayed lower MIC values (Table 1).

Regarding the specific lytic activity $\left(\Delta \mathrm{OD}_{600} \times \min ^{-1} \times \mu \mathrm{M}^{-1}\right)$, LysRODI and CHAPSH3b showed similar results and were again the most active $(p<0.05)$ (Table 2$)$.

\section{Protein Stability and Activity Is Influenced by Different Physicochemical Conditions}

The stability of the proteins and the influence of two environmental parameters (temperature and $\mathrm{pH}$ ) on the

TABLE 2 | Specific lytic activity of the proteins against $S$. aureus Sa9 and $S$. epidermidis F12.

Specific lytic activity

\begin{tabular}{lcc}
\hline Protein & S. aureus Sa9 & S. epidermidis $\mathbf{F 1 2}^{\mathbf{a}}$ \\
\hline LysRODI & $0.24 \pm 0.02$ & $0.12 \pm 0.03$ \\
LySA72 & $0.09 \pm 0.00$ & N.A. \\
CHAPSH3b & $0.20 \pm 0.02$ & $0.11 \pm 0.02$
\end{tabular}

${ }^{a}$ Data are expressed as the mean \pm standard deviation of three replicates and expressed as $\Delta D O_{600} \times \mu M^{-1} \times \mathrm{min}^{-1}$.

N.A.: Not active. lytic activity against $S$. aureus Sa9 was determined. The exposure to temperatures over $40^{\circ} \mathrm{C}$ completely inactivated LysA72, while LysRODI showed a decreased activity at this temperature and was inactivated at higher temperatures. $\mathrm{CHAPSH} 3 \mathrm{~b}$ completely retained its activity at $40^{\circ} \mathrm{C}$, and even showed some residual activity at higher temperatures (Figure 1A). Regarding $\mathrm{pH}$, the most stable protein was CHAPSH3b, which showed a high activity in a broad range of $\mathrm{pH}$ (3-11). In turn, LysRODI and LysA72 showed the highest activity at $\mathrm{pH} 7$, albeit LysRODI was active within pH 5 and 9 (Figure 1B).

Finally, the influence of different ions $\left(\mathrm{KCl}, \mathrm{MgCl}_{2}\right.$, $\mathrm{NaCl}, \mathrm{MnCl}_{2}, \mathrm{ZnCl}_{2}, \mathrm{CaCl}_{2}$ ) on lytic activity was also evaluated. LysRODI was completely inactivated in the presence of $\mathrm{MnCl}_{2}, \mathrm{ZnCl}_{2}$ and $\mathrm{MgCl}_{2}$. Interestingly, $\mathrm{ZnCl}_{2}$ also resulted inhibitory for LysA72 and CHAPSH3b. Of note, the activity of proteins LysRODI, LysA72 and $\mathrm{CHAPSH} 3 \mathrm{~b}$ increased $\sim 2$-fold by adding $\mathrm{NaCl}, \mathrm{CaCl}_{2}$ and $\mathrm{KCl}$ (data not shown).

\section{Chimeric Protein LysRODI and CHAPSH3b Lyse Staphylococcal Cells Faster Than LysA72}

To determine the killing rate of phage lytic proteins, time-kill curve experiments were performed using $S$. aureus Sa9 cultures $\left(10^{7} \mathrm{CFU} / \mathrm{ml}\right)$ treated with equimolar amounts of each protein $(0.1 \mu \mathrm{M})$. In these assays, LysRODI and CHAPSH3b showed a higher antibacterial activity than LysA72, as both of them reduced the bacterial counts under the detection limit after 30 min (Figure 2). Of note, CHAPSH3b was faster than the other two proteins since a $4.5 \mathrm{log}$ reduction in viable counts was observed after only $2 \mathrm{~min}$ of incubation. At this same time, a $3.5 \log$ reduction was observed for LysRODI. Unfortunately, LysA72 did not achieve a complete elimination of the bacteria (Figure 2).
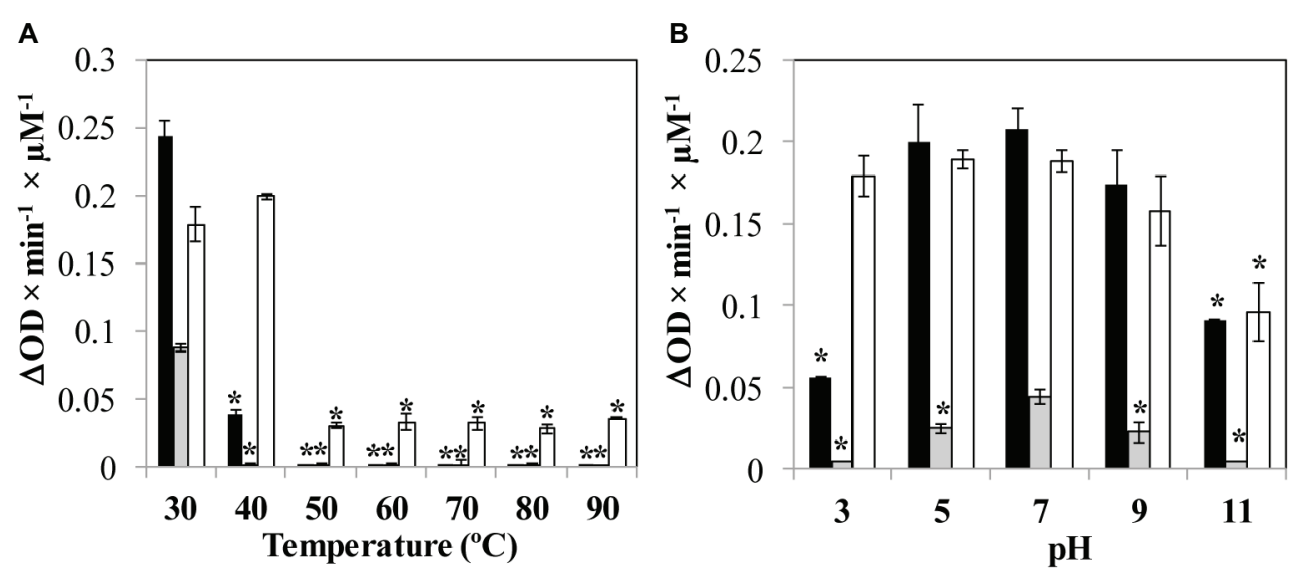

FIGURE 1 | Influence of environmental parameters (A) temperature and (B) pH on protein activity. Specific lytic activity of the proteins is calculated against S. aureus Sa9. Bars represent the activity $\left(\Delta \mathrm{DO}_{600} \times \min -^{1} \times \mu \mathrm{M}-{ }^{1}\right)$ of each protein (LysRODI, black; LysA72, gray and CHAPSH3b white). Data are the mean \pm standard deviation of three biological replicates. Asterisks indicate statistical differences $(p<0.05$; Student's $t$-test) between the specific lytic activity when the protein is submitted to the temperature or $\mathrm{pH}$ treatment with the activity observed when the protein is tested at $37^{\circ} \mathrm{C}$ in $\mathrm{NaPi}$ buffer, $\mathrm{pH}=7.4$. The data were expressed as the mean \pm standard deviation of three biological replicates. 


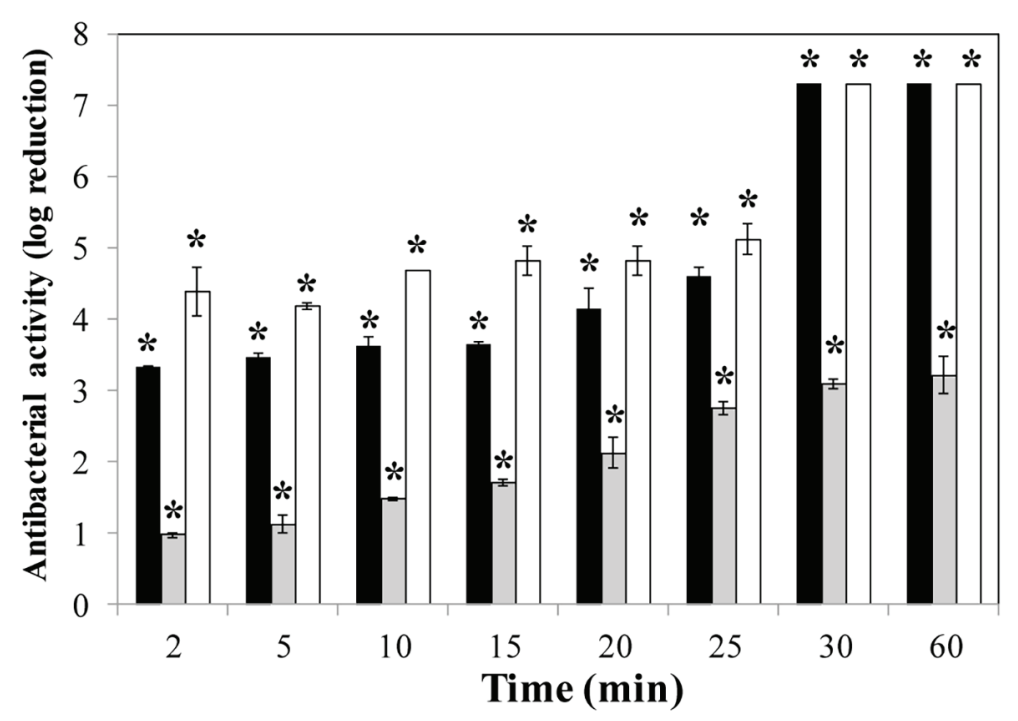

FIGURE 2 | Time-kill curve of S. aureus Sa9 treated with equimolar amounts $(0.1 \mu \mathrm{M})$ of proteins (LysRODI, black; LysA72, gray and CHAPSH3b white). Results (means \pm standard deviation of three replicates) are reported as bacterial reduction quantified as the relative inactivation in log units (log ${ }_{10}\left[\mathrm{~N}_{0} / \mathrm{N}_{\mathrm{i}}\right]$; $\mathrm{N}_{0}$ as the initial number of untreated cells and $\mathrm{N}_{\mathrm{i}}$ as the number of residual cells counted after treatment). Bars having an asterisk are statistically different $(p<0.05)$ from the untreated control according to the Student's t-test. The detection limit is $10 \mathrm{CFU} / \mathrm{ml}$.

\section{Neither the Endolysins nor CHAPSH3b Lead to Staphylococcal Resistance Development}

To assess the ability of $S$. aureus and $S$. epidermidis to develop resistance against the phage lytic proteins, we attempted to select resistant mutants in liquid medium by serial subculture of staphylococcal strains in the presence of sub-inhibitory concentrations of the proteins. Lysostaphin was used as a positive control. After 10 rounds of exposure, MIC values were determined and compared with the ones obtained previously for two strains susceptible to the three lytic proteins (Table 3). As expected, the MIC values of lysostaphin increased by more than 32-fold, whereas the studied proteins did not select resistant bacteria.

\section{LysRODI Shows the Highest and Fastest Antibiofilm Activity in vitro}

Four different antibiofilm parameters were calculated for the endolysins LysRODI and LysA72 and compared to those previously obtained for CHAPSH3b (Gutierrez et al., 2017) (Table 4). The $\mathrm{MBEC}_{50}$ and the LOABE were calculated after treating $8 \mathrm{~h}$ preformed biofilms of $S$. aureus 15,981 (a strong biofilm former) with increasing concentrations of the proteins (0.14-9.15 $\mu \mathrm{M}$ for LysRODI and 0.21-13.42 $\mu \mathrm{M}$ for LysA72) (Table 4). LysA72 exhibited the highest MBEC $_{50}$ (minimum biofilm eradication concentration) and LOABE (lowest concentration of protein needed to observe an antibiofilm effect) values indicating that a higher concentration is necessary to attain the same antibiofilm effect. In turn, LysRODI possessed the lowest $\mathrm{MBEC}_{50}$ value of all three proteins, since only $2.21 \mu \mathrm{M}$ could remove $50 \%$ of the biofilm.
In order to compare the specific antibiofilm activity of the proteins, an equimolar amount of protein $(7 \mu \mathrm{M})$ was used to treat the biofilms (Table 4). Interestingly, LysRODI showed the highest specific antibiofilm activity $(\sim 4.5)$, being 11 and 38 times more active than CHAPSH3b and LysA72, respectively. This result indicates a faster antibiofilm activity of LysRODI, since maximum biofilm removal was achieved $1 \mathrm{~h}$ after treatment, while for CHAPSH3b and LysA72 the maximum reduction was achieved after 2.5 and $5 \mathrm{~h}$, respectively (data not shown). Moreover, the percentage of biofilm reduction after $16 \mathrm{~h}$ of treatment with LysRODI was $94 \%$ but only 25 and $17 \%$ when treated with CHAPSH3b and LysA72, respectively (Table 4).

\section{Both LysRODI and CHAPSH3b Are Safe and Show Anti-Staphylococcal Activity in Zebrafish}

Based on the in vitro activity data, LysRODI and CHAPSH3b were assessed in vivo in a zebrafish model. Initially, acute toxicity was evaluated by exposure of zebrafish embryos to $1 \times$ MIC of LysRODI $(0.5 \mu \mathrm{M})$ and CHAPSH3b $(0.7 \mu \mathrm{M})$. As expected, treatment with $1 \mathrm{mg} / \mathrm{ml}$ of paracetamol was toxic for the embryos (Figure 3A). In protein-treated groups embryos survived in presence of LysRODI and CHAPSH3b (>92\% survival), indicating a non-toxic effect (Figure 3A).

Once established the lack of toxicity of the lytic proteins, their protective effect against a subsequent bacterial challenge was evaluated in a systemic model of infection. As expected, the untreated zebrafish control infected with $S$. aureus showed a $33.3 \%$ of cumulative survival after $72 \mathrm{~h}$ (Figure 3B). In contrast, treatment with three different doses $(0.5 \times \mathrm{MIC}$, $1 \times \mathrm{MIC}$ or $3 \times \mathrm{MIC})$ of LysRODI $(0.25,0.5$ and $1 \mu \mathrm{M})$ or 
TABLE 3 | MIC values of S. aureus Sa9 and S. epidermidis F12 before (Control) and after (Treated) exposure to sub-lethal concentrations of different recombinant phage proteins.

\begin{tabular}{|c|c|c|c|c|c|}
\hline \multirow[t]{2}{*}{ Strain } & \multirow[t]{2}{*}{ Assay } & \multicolumn{4}{|c|}{$\operatorname{MIC}(\mu \mathrm{M})^{\mathrm{a}}$} \\
\hline & & LysRODI & LysA72 & CHAPSH3b & Lysostaphin \\
\hline \multirow[t]{2}{*}{ S. aureus Sa9 } & Control & 0.57 & 1.47 & 0.33 & 0.43 \\
\hline & Treated ${ }^{\mathrm{b}}$ & $0.49 \pm 0.11$ & $1.39 \pm 0.24$ & $0.39 \pm 0.16$ & $>27.6$ \\
\hline \multirow[t]{2}{*}{ S. epidermidis LO5081 } & Control & 1.14 & $2.94 \pm 0.09$ & 0.33 & 1.73 \\
\hline & Treated $^{b}$ & $1.17 \pm 0.06$ & $2.48 \pm 0.11$ & $0.32 \pm 0.01$ & $>27.6$ \\
\hline
\end{tabular}

aMinimum inhibitory concentration (MIC) expressed as $\mu \mathrm{M}$.

${ }^{b}$ MIC values after 10 rounds of exposure to protein followed by five additional rounds without protein.

Data represent the mean \pm standard deviation of three independent biological repeats.

TABLE 4 | Antibiofilm activity of LysRODI, LysA72 and CHAPSH3b.

\begin{tabular}{lcccc}
\hline Protein & $\begin{array}{c}\mathbf{M B E C}_{50} \\
(\boldsymbol{\mu} \mathbf{M})^{\mathbf{a}}\end{array}$ & $\begin{array}{c}\text { LOABE } \\
(\boldsymbol{\mu} \mathbf{M})^{\mathbf{b}}\end{array}$ & $\begin{array}{c}\text { Specific } \\
\text { antibiofilm } \\
\text { activity }^{\mathbf{c}}\end{array}$ & $\begin{array}{c}\text { Biofilm } \\
\text { reduction }(\%)^{\mathbf{d}}\end{array}$ \\
\hline LysRODI & $2.21 \pm 0.22$ & 1.14 & $4.53 \pm 0.63$ & $94.23 \pm 4.59$ \\
LySA72 $_{\text {CHAPSH3b }}$ & $13.26 \pm 3.87$ & 13.42 & $0.12 \pm 0.02$ & $17.13 \pm 2.63$ \\
CHAP & $4.4 \pm 1.2$ & 1.2 & $0.38 \pm 0.03$ & $25.62 \pm 6.23$
\end{tabular}

${ }^{a} M B E C_{50}$ : minimum biofilm eradicating concentration that removes $50 \%$ of the biofilm. ${ }^{b} \mathrm{LOABE}$ : lowest antibiofilm effect. MBEC $C_{50}$ and $L O A B E$ were calculated for $S$. aureus 15,981 8 h mature biofilms treated with increasing concentrations of protein.

'Specific antibiofilm activity expresses as the mean \pm standard deviation of ( $\Delta$ baseline normalized $\mathrm{Cl} \times \mathrm{mM}^{-1} \times \mathrm{min}^{-1}$ ) using $7 \mu \mathrm{M}$ of protein.

$\%$ of biofilm reduction expresses as the mean \pm standard deviation $(n=3)$ of normalized $\mathrm{Cl}$ using $7 \mu \mathrm{M}$ of protein at $16 \mathrm{~h}$ post-treatment and $37^{\circ} \mathrm{C}$.

${ }^{-T}$ These data have been previously published (22). All data represent mean \pm standard deviation of three biological replicates.

CHAPSH3b $(0.35,0.7$ and $1.4 \mu \mathrm{M})$ significantly improved survival of the infected animals ( $p=0.0028$ and $p=0.0002$, respectively), with similar levels of efficacy obtained for both proteins testing 3 different concentrations ( $p>0.05$; Supplementary Table 1). In fact, at $72 \mathrm{~h}$ after treatment, MIC and $0.5 \times$ MIC of both proteins allowed a 66.7 and $83.3 \%$ survival, respectively, although these differences were not statistically significant $(p<0.05)$. Of note, $3 \times$ MIC of LysRODI led to a $77.7 \%$ survival, which is not statistically significant compared to the other two concentrations tested $(p<0.05)$. Meanwhile, $3 \times$ MIC of CHAPSH3b led to a $94.4 \%$ of survival which is statistically significant $(p>0.05)$ when compared with $0.5 \times$ MIC, indicating a dose-dependent effect. Besides, the treatment with $3 \times$ MIC of CHAPSH3b or LysRODI gave similar results $(p<0.05)$ Moreover, no viable bacteria could be detected in any of the surviving fish $72 \mathrm{~h}$ post infection (data not shown).

\section{LysRODI Prevents Staphylococcal Infection in a Mouse Model of Mastitis}

LysRODI was selected to evaluate its in vivo ability to prevent $S$. aureus and $S$. epidermidis mastitis in a murine model, since it showed the most effective antibiofilm activity and its in vivo activity was dose-independent in a zebrafish infection model. Intramammary treatment with LysRODI in mice prevented the mastitis lesions (Figure 4A) and significantly reduced the bacterial virulent infection caused by $S$. aureus $(p<0.001)$ or $S$. epidermidis $(p<0.0001)$ (Figure 4B). Indeed, mice treated with the endolysin showed healthy mammary glands in terms of color, texture, size and absence of edema or hyperemia, in contrast to untreated controls (Figure 4A). Regarding the bacterial burden, LysRODI treated mice showed a reduction of 3-4 log units compared to the untreated mice controls (Figure 4B).

\section{DISCUSSION}

Phage lytic proteins could potentially reduce the incidence of animal diseases while avoiding antibiotic use. In the case of $S$. aureus and $S$. epidermidis infections, prevention is perhaps a better strategy than treatment. For instance, once a staphylococcal infection is established, the bacterial cells can be found in an intracellular stage or forming antibiotic-resistant biofilms. Previous studies have shown that phage lytic proteins can be effective as a preventive strategy against staphylococcal infections by decolonization of skin and nares in murine models (Fenton et al., 2010; Pastagia et al., 2011; Paul et al., 2011).

The activity and stability of three proteins LysRODI, LysA72 and CHAPSH3b was firstly evaluated in vitro against staphylococcal strains isolated from human and farm animals. Activity was assessed by muralytic, MIC and time-kill assays (Schmelcher et al., 2012a). The specific lytic activity of LysRODI was similar to that of the well-known endolysin LysK ( $\sim 0.04$ $\left.\Delta \mathrm{DO}_{600} \times \min ^{-1} \times \mu \mathrm{g}^{-1}\right)$ (Becker et al., 2008), with which it shares $98 \%$ of protein similarity. Interestingly, LysRODI and CHAPSH3b turned out to be active against all the species of staphylococci tested. This broad activity range is quite common among staphylococcal endolysins since their cell wall binding domain (CBD) have proven to recognize different staphylococcal species (Becker et al., 2009; Schmelcher et al., 2015b; Gutierrez et al., 2018). In addition to the CBD, the broad activity range can also be explained by the cleavage sites of the CHAP and amidase domains of staphylococcal endolysins, which are conserved in the peptidoglycan of both $S$. aureus and other staphylococcal species. Surprisingly, the activity of LysA72 seems to be restricted to $S$. aureus and $S$. haemolyticus strains. Unfortunately, it is difficult to determine if this narrow range is related to the protein structure because there is only one protein with a high similarity (98\%) to LysA72 that has been 
A

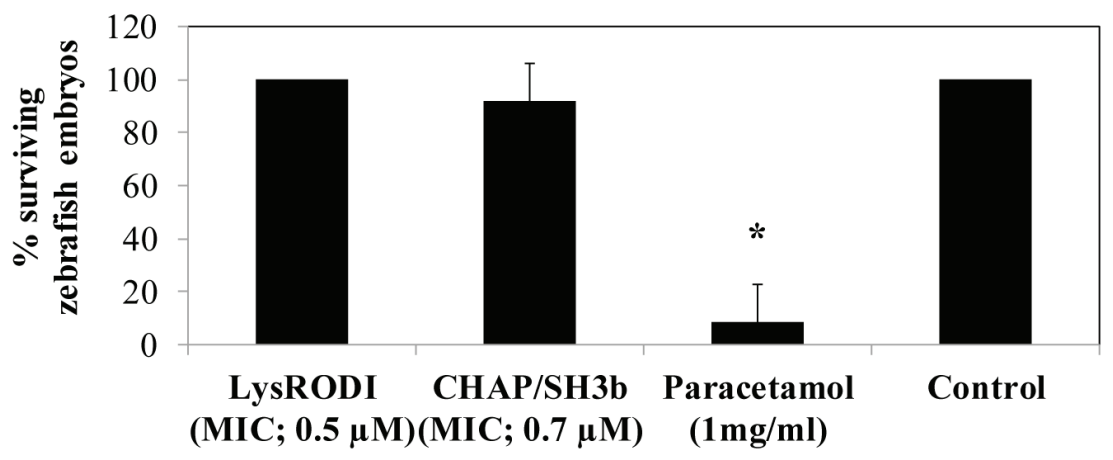

B

I

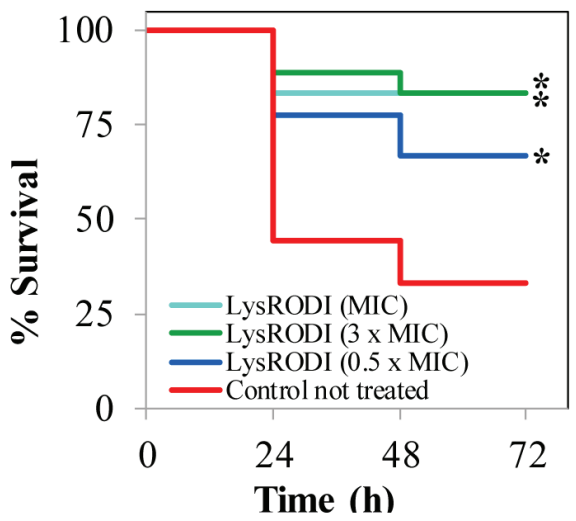

II

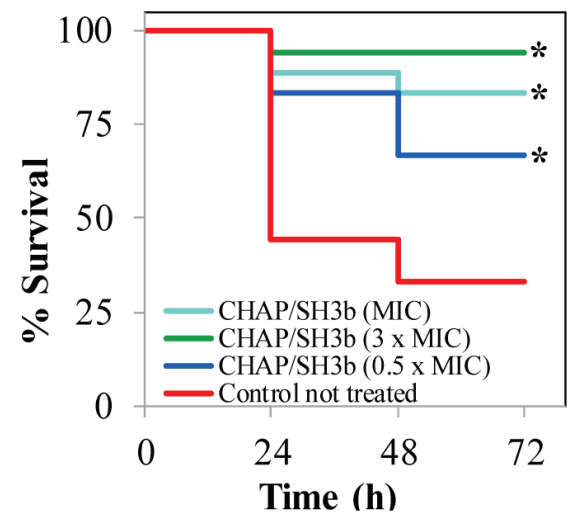

FIGURE 3 | Evaluation of safety and activity of LySRODI and CHAPSH3b using a zebrafish model. (A) Acute toxicity of the proteins was tested by exposure of zebrafish embryos $(n=8)$ to $1 \times$ MIC of LysRODI or CHAPSH3b. Medium E3 was used as a negative control and $1 \mathrm{mg} / \mathrm{ml}$ paracetamol, as a positive control. Bars represent mean \pm standard deviation $(n=24)$ of triplicate experiments. The asterisk indicates statistical differences $(p<0.05)$ vs untreated control by Chi-square test. (B) Efficacy of LysRODI (I) and CHAPSH3b (II) in a zebrafish model infected with $\sim 10^{5} \mathrm{CFU} /$ fish of S. aureus when treating with $0.5 \times \mathrm{MIC}, 1 \times \mathrm{MIC}$ and $3 \times$ MIC. Kaplan-Meier graphs represent the percentage of cumulative survival zebrafish $(n=18)$ observed at 24,48 and $72 \mathrm{~h}$. Asterisks indicate significant differences $(p<0.05)$ vs. the untreated control according to the Kaplan-Meier cumulative survival plot and statistically compared by the Log-Rank test.

purified to date; endolysins from phage phi12. The activity of this endolysin could not be determined due to cell aggregation during the turbidity assay, which led to an increase in optical density (Sass and Bierbaum, 2007). This phenomenon of cell aggregation was explained by the authors because of an aminoacidic exchange in position 260 (Amidase-3 domain), which is only present in the endolysin from phage phi12 but not in LysA72 or other related endolysins (Becker et al., 2009).

Protein stability under a wide range of environmental conditions is very important for the development of endolysinbased antimicrobial products, especially those aimed for topical application. Both CHAPSH3b and LysRODI retained full activity for at least $30 \mathrm{~min}$ in skin-simulated conditions ( $\mathrm{pH}$ between 4 and 7 , temperature from 26 to $38^{\circ} \mathrm{C}$ ) (Lambers et al., 2006). The activity of LysRODI under physicochemical disadvantages are in accordance with those previously obtained for LysK, both active within the same $\mathrm{pH}$ range (5-9), temperature (stable until $40^{\circ} \mathrm{C}$ ) and are positively influenced by the addition of $\mathrm{NaCl}$ (Becker et al., 2008).

Time-killing assays provide a good indication of the speed at which a given antimicrobial can kill bacterial cells, which in turn is indicative of its effectiveness to prevent infection progress.
In this study, a similar time-killing speed was observed for LysRODI and CHAPSH3b, whereas LysA72 was slower and never caught up with the other two proteins in terms of total bacterial elimination. Generally, the quicker activity of endolysins is consistent with previous reports due to the high affinity of CBDs to the bacterial peptidoglycan (Liu et al., 2015). Of note, the ability of LysRODI and CHAPSH3b to remove $7 \mathrm{log}$ units of bacteria is even higher than that of CF-301, a lysin encoded within a prophage of the Streptococcus suis genome, whose domain arrangement is very similar to that of CHAPSH3b (CHAP domain and $\mathrm{SH} 3 \mathrm{~b}$ domain). In fact, addition of CF-301at its minimum inhibitory concentration only led to a reduction in bacterial cells of about $3 \log$ units within $30 \mathrm{~min}$ (Schuch et al., 2014).

Attachment to host tissues and biofilm formation are processes of key importance for persistence and progress of bacterial infections (Otto, 2013). In terms of preventive treatment, any successful strategy should hinder this process and display antibiofilm activity. Removal of preformed biofilms, however, is expected to be hindered by their maturation state and their complex threedimensional structure, which limits access of antimicrobials to their target bacteria. Nonetheless, there are promising results with phage lytic proteins. In this study, LysRODI displayed the 


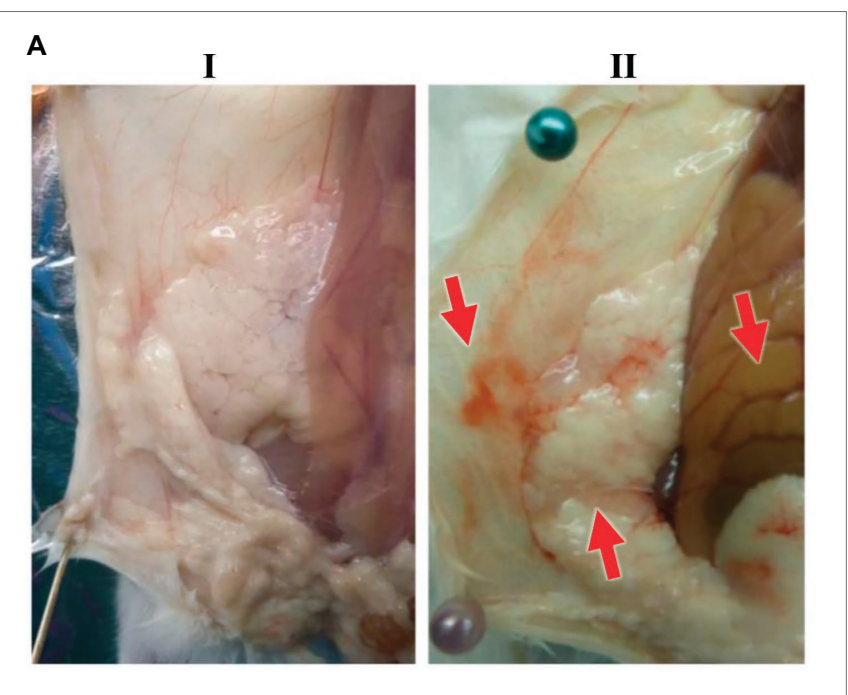

B

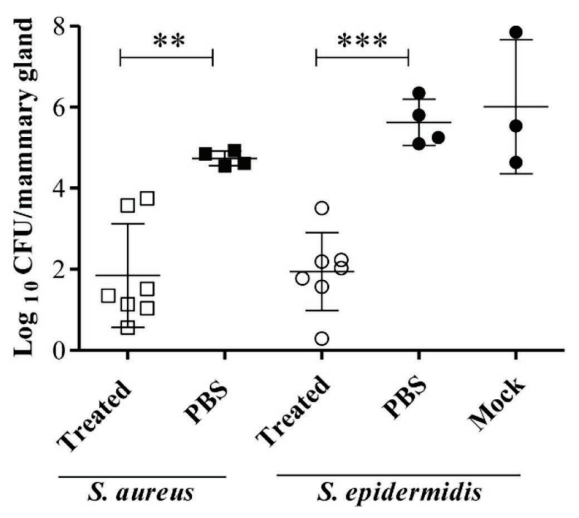

FIGURE 4 | Efficacy of LysRODI preventive treatment in a mastitis mouse model. CD1 lactating mice at breastfeeding day 10 were treated by intramammary administration of $24 \mu \mathrm{g}$ of LysRODI and challenged $90 \mathrm{~min}$ later with $5 \times 10^{4} \mathrm{CFU} /$ mice of $S$. epidermidis or S. aureus. Mice inoculated with PBS or mock buffer were used as controls of staphylococcal infection. (A) Macroscopic aspect of R4-R5 mammary glands of mice treated with (I) treated $24 \mu \mathrm{g} /$ mouse of LysRODI or (II) PBS and infected with S. aureus Sa10. Red arrows indicate symptoms of edema, hyperemia and changes in color of an infected mammary gland. (B) Preventive efficacy of LysRODI against $S$. aureus and $S$. epidermidis mammary glands infections in CD1 mice, determined by the mean \pm standard deviation of individual $\log _{10} \mathrm{CFU} /$ mammary gland. White symbols are Lys-RODI treated mice; black symbols are untreated mice, inoculated with either PBS or mock sterile buffers; circles and squares represent, respectively, $S$. aureus and $S$. epidermidis challenged mice. The number of CFU was determined in each R4-R5 mammary gland, at $18 \mathrm{~h}$ post-challenge. Statistical comparison of means was performed by ANOVA and post-hoc PLSD tests: ${ }^{* *} p<0.001$ and ${ }^{* * * *} p<0.0001$ vs. control (PBS or mock).

best antibiofilm activity on the basis of different antibiofilm parameters. Generally speaking, it has been demonstrated that complete removal of a mature biofilm (more than $24 \mathrm{~h}$ old biofilms) needs a second endolysin treatment (Gutiérrez et al., 2014) or a combined treatment with antibiotics (Chopra et al., 2015). Indeed, although CF-301 showed a potent antibiofilm activity $\left(\mathrm{MBEC}_{90}\right.$ values from $9 \mathrm{nM}$ to $\left.0.3 \mu \mathrm{M}\right)$, it was improved when combining with lysostaphin (Schuch et al., 2017).
We also evaluated the in vivo activity of LysRODI and CHAPSH3b, by using a zebra fish model, which has been deemed suitable for assessing the efficacy of antimicrobial agents before proceeding to mammalian studies (Díez-Martínez et al., 2013). Initially, we observed that none of the proteins was toxic for zebrafish embryos at the dose tested. In a subsequent experiment, a single dose of either protein significantly reduced mortality of zebrafish by $S$. aureus in a systemic model of infection. Nevertheless, the treatment with CHAPSH3b seems to be dose dependent. Due to the positive results obtained in the zebrafish model, we decided to assess the efficacy of the protein that resulted in the best overall results (LysRODI) in a murine mastitis model. Even though the effectiveness of endolysins has been demonstrated in vivo, there is a lack of research regarding their safety and toxicity. Nevertheless, safety studies carried out with endolysins $\mathrm{Cpl}-1$ and $\mathrm{PaI}$ supported the safety of these compounds, since there was no significant pro-inflammatory response, hypersensitivity or allergic reaction after injecting $0.3 \mathrm{mg}$ per mouse $(15 \mathrm{mg} / \mathrm{kg})$ of each protein (Harhala et al., 2018). Moreover, toxicity in mammals is not a worrying issue since it has been proven that intravenous administration of endolysin SAL-200 (highly similar to LysRODI) showed no signs of toxicity in rodents after single- and repeateddose experiments (Jun et al., 2014). Moreover, SAL-200 was also administered (single intravenous) among healthy volunteers, with no adverse side-effects reported (Jun et al., 2017).

The effectiveness of endolysins against staphylococcal infections in animal models has been widely demonstrated (Gutierrez et al., 2018). Specifically, for mastitis treatment, two promising papers support the use of phage lytic proteins as therapeutic agents. Schmelcher et al. (2012b) demonstrated that the infusion of a combination of proteins ( $\chi \mathrm{SA} 2-\mathrm{E}-\mathrm{LysK}-\mathrm{SH} 3 \mathrm{~b}$ and lysostaphin, $12.5 \mu \mathrm{g}$ each/gland) caused a 3.36-log decrease in viable bacteria and a reduction in inflammation indicators in a murine mastitis. More recently, preliminary results showed that endolysin Trx-SA1 (20 mg once per day) could effectively control mild clinical mastitis caused by S. aureus in cows (Fan et al., 2016). Nonetheless, an endolysin-based treatment could be challenging, as bacterial cells could form biofilms on host tissues or live intracellularly. For this reason, it would be preferable to perform preventive rather than therapeutic treatments. However, few reports have been published about prophylaxis of infectious diseases caused by $S$. aureus using phage lytic proteins and none regarding $S$. epidermidis. Indeed, the emergence of $S$. aureus resistance to mupirocin has led clinicians to rethink its use for nasal decolonization in certain groups of patients (Coates et al., 2009). In contrast, phage lytic proteins like ClyS have shown a greater potential than mupirocin for topical eradication of this bacterium and a lower potential for resistance development (Pastagia et al., 2011). Here, we proved that intrammamary infusion of $24 \mu \mathrm{g}$ $(0.43 \mu \mathrm{M})$ of LysRODI can protect mice from S. aureus and $S$. epidermidis mastitis. It is also worth noting that no resistant bacteria were obtained after sub-lethal exposure to the proteins. Previous studies found similar results with other endolysins (Pastagia et al., 2011; Gutierrez et al., 2018), with the exception of LysK, which led to a 42 -fold MIC increase in S. aureus liquid cultures (Becker et al., 2016). Nonetheless, in the case 
of bovine mastitis, the use of endolysins as prophylaxis (every animal is treated on a regular basis by intramammary infusion) or as treatment needs to be evaluated in detail, due to the expected high cost derived from production of these enzymes.

Overall, phage lytic proteins offer ideal features, including their easy manipulation for designing new proteins with improved activity and the lack of bacterial resistance development, to be used as therapeutic agents and as decolonizing products for veterinary applications.

\section{DATA AVAILABILITY STATEMENT}

All datasets generated for this study are included in the article/Supplementary Material.

\section{ETHICS STATEMENT}

The animal study was reviewed and approved by registration code ES/31-2016-000002-CR-SU-US.

\section{AUTHOR CONTRIBUTIONS}

PG, AR, and MG conceived and designed the experiments. DG, LF, and SP performed the experiments related with the in vitro characterization of the proteins. VG performed the murine model experiments. DG and VG analyzed the data. All the authors wrote the paper.

\section{FUNDING}

This research study was supported by grants AGL2015-65673-R (MINECO/FEDER/EU, Spain), EU ANIWHA ERA-NET (BLAAT

\section{REFERENCES}

Altschul, S. F., Gish, W., Miller, W., Myers, E. W., and Lipman, D. J. (1990). Basic local alignment search tool. J. Mol. Biol. 215, 403-410. doi: 10.1016/ S0022-2836(05)80360-2

Bastiaan Vliegenthart, A. D., Tucker, C. S., Del Pozo, J., and Dear, J. W. (2014). Zebrafish as model organisms for studying drug-induced liver injury. $\mathrm{Br}$. J. Clin. Pharmacol. 78, 1217-1227. doi: 10.1111/bcp.12408

Becker, S. C., Foster-Frey, J., and Donovan, D. M. (2008). The phage K lytic enzyme LysK and lysostaphin act synergistically to kill MRSA. FEMS Microbiol. Lett. 287, 185-191. doi: 10.1111/j.1574-6968.2008.01308.x

Becker, S. C., Foster-Frey, J., Stodola, A. J., Anacker, D., and Donovan, D. M. (2009). Differentially conserved staphylococcal SH3b_5 cell wall binding domains confer increased staphylolytic and streptolytic activity to a streptococcal prophage endolysin domain. Gene 443, 32-41. doi: 10.1016/j.gene.2009.04.023

Becker, S. C., Roach, D. R., Chauhan, V. S., Shen, Y., Foster-Frey, J., Powell, A. M., et al. (2016). Triple-acting lytic enzyme treatment of drug-resistant and intracellular Staphylococcus aureus. Sci. Rep. 6:25063. doi: $10.1038 /$ srep25063

Blazquez, B., Fresco-Taboada, A., Iglesias-Bexiga, M., Menendez, M., and Garcia, P. (2016). PL3 amidase, a tailor-made lysin constructed by domain shuffling with potent killing activity against pneumococci and related species. Front. Microbiol. 7:1156. doi: 10.3389/fmicb.2016.01156
ID: 67)/PCIN-2017-001 (AEI/FEDER/EU, Spain), Proyecto Intramural CSIC 201770E016, IDI/2018/000119 (Asturias Innovation 2018-2020, Principado de Asturias, Spain) and FEDER/EU. LF is a "Marie Curie Clarin-Cofund" postdoctoral fellow. SP has a postdoctoral fellowship CONACYT (México). PG and AR are members of the FWO Vlaanderen funded "Phagebiotics" research community (WO.016.14) and the bacteriophage network FAGOMA.

\section{ACKNOWLEDGMENTS}

The authors acknowledge the support of the publication fee by the CSIC Open Access Publication Support Initiative through its Unit of Information Resources for Research (URICI). We thank Dr. Karl Pedersen from the (DTU-Vet, Copenhaguen, Denmark) and Dr. Anders Nilsson (Stockholm University, Stockholm, Sweden) for provide the MRSA strains, Dr. Juan Miguel Rodríguez (Complutense University of Madrid. Madrid, Spain) for provide the staphylococcal strains isolated from lactating woman and Dr. Alejandro Toledo-Arana (Instituto de Agrobiotecnología, CSIC-UPNa-Gobierno de Navarra, Mutilva, Spain) for provide the S. aureus 15981 strain. Contribution of Leyre Clara Blanco Antón, which was made possible by an FSE-CSIC grant to the Animal Health group of Instituto de Agrobiotecnología (CSIC-UPNa-Gobierno de Navarra, Mutilva, Spain) in 2017-2018, is also acknowledged. We finally thank Roxana Calvo (IPLA-CSIC) for her technical assistance in this work.

\section{SUPPLEMENTARY MATERIAL}

The Supplementary Material for this article can be found online at: https://www.frontiersin.org/articles/10.3389/fmicb.2020.00007/ full\#supplementary-material
CLSI (2015). Performance standards for antimicrobial susceptibility testing; twentyfifth informational supplement. CLSI approved document M100-S25. Wayne, PA: Clinical and Laboratory Standards Institute.

Coates, T., Bax, R., and Coates, A. (2009). Nasal decolonization of Staphylococcus aureus with mupirocin: strengths, weaknesses and future prospects. J. Antimicrob. Chemother. 64, 9-15. doi: 10.1093/jac/dkp159

Czaplewski, L., Bax, R., Clokie, M., Dawson, M., Fairhead, H., Fischetti, V. A., et al. (2016). Alternatives to antibiotics-a pipeline portfolio review. Lancet Infect. Dis. 16, 239-251. doi: 10.1016/S1473-3099(15)00466-1

Chang, Y., Yoon, H., Kang, D. H., Chang, P. S., and Ryu, S. (2017). Endolysin LysSA97 is synergistic with carvacrol in controlling Staphylococcus aureus in foods. Int. J. Food Microbiol. 244, 19-26. doi: 10.1016/j.ijfoodmicro.2016.12.007

Chopra, S., Harjai, K., and Chhibber, S. (2015). Potential of sequential treatment with minocycline and $S$. aureus specific phage lysin in eradication of MRSA biofilms: an in vitro study. Appl. Microbiol. Biotechnol. 99, 3201-3210. doi: 10.1007/s00253-015-6460-1

Delgado, S., Arroyo, R., Jiménez, E., Marín, M. L., del Campo, R., Fernández, L. et al. (2009). Staphylococcus epidermidis strains isolated from breast milk of women suffering infectious mastitis: potential virulence traits and resistance to antibiotics. BMC Microbiol. 9:82. doi: 10.1186/1471-2180-9-82

Díez-Martínez, R., de Paz, H. D., Bustamante, N., García, E., Menéndez, M., and García, P. (2013). Improving the lethal effect of cpl-7, a pneumococcal phage lysozyme with broad bactericidal activity, by inverting the net charge 
of its cell wall-binding module. Antimicrob. Agents Chemother. 57, 5355-5365. doi: 10.1128/AAC.01372-13

Donovan, D. M., Lardeo, M., and Foster-Frey, J. (2006). Lysis of staphylococcal mastitis pathogens by bacteriophage phil1 endolysin. FEMS Microbiol. Lett. 265, 133-139. doi: 10.1111/j.1574-6968.2006.00483.x

European Commission (2017). A European one health action plan against antimicrobial resistance AMR. Action Plan European Commission. Brussels: European Commission, 1-24.

Fan, J., Zeng, Z., Mai, K., Yang, Y., Feng, J., Bai, Y., et al. (2016). Preliminary treatment of bovine mastitis caused by Staphylococcus aureus, with trx-SA1, recombinant endolysin of $S$. aureus bacteriophage IME-SA1. Vet. Microbiol. 191, 65-71. doi: 10.1016/j.vetmic.2016.06.001

Fenton, M., Casey, P. G., Hill, C., Gahan, C. G., Ross, R. P., McAuliffe, O., et al. (2010). The truncated phage lysin $\mathrm{CHAP}(\mathrm{k})$ eliminates Staphylococcus aureus in the nares of mice. Bioeng. Bugs 1, 404-407. doi: 10.4161/bbug.1.6.13422

Fernandez, L., Gonzalez, S., Campelo, A. B., Martinez, B., Rodriguez, A., and Garcia, P. (2017). Downregulation of autolysin-encoding genes by phagederived lytic proteins inhibits biofilm formation in Staphylococcus aureus. Antimicrob. Agents Chemother. 61:e02724-16. doi: 10.1128/AAC.02724-16

Fischetti, V. A. (2010). Bacteriophage endolysins: a novel anti-infective to control gram-positive pathogens. Int. J. Med. Microbiol. 300, 357-362. doi: 10.1016/j. ijmm.2010.04.002

García, P., Martínez, B., Obeso, J. M., Lavigne, R., Lurz, R., and Rodríguez, A. (2009). Functional genomic analysis of two Staphylococcus aureus phages isolated from the dairy environment. Appl. Environ. Microbiol. 75, 7663-7673. doi: 10.1128/AEM.01864-09

García, P., Martínez, B., Rodríguez, L., and Rodríguez, A. (2010). Synergy between the phage endolysin LysH5 and nisin to kill Staphylococcus aureus in pasteurized milk. Int. J. Food Microbiol. 141, 151-155. doi: 10.1016/j. ijfoodmicro.2010.04.029

Gomes, F., Saavedra, M. J., and Henriques, M. (2016). Bovine mastitis disease/ pathogenicity: evidence of the potential role of microbial biofilms. Pathog. Dis. 74:ftw006. doi: 10.1093/femspd/ftw006

Gutierrez, D., Briers, Y., Rodriguez-Rubio, L., Martinez, B., Rodriguez, A., Lavigne, R., et al. (2015). Role of the pre-neck appendage protein (Dpo7)

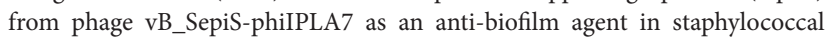
species. Front. Microbiol. 6:1315. doi: 10.3389/fmicb.2015.01315

Gutierrez, D., Fernandez, L., Martinez, B., Ruas-Madiedo, P., Garcia, P., and Rodriguez, A. (2017). Real-time assessment of Staphylococcus aureus biofilm disruption by phage-derived proteins. Front. Microbiol. 8:1632. doi: 10.3389/ fmicb.2017.01632

Gutierrez, D., Fernandez, L., Rodriguez, A., and Garcia, P. (2018). Are phage lytic proteins the secret weapon to kill Staphylococcus aureus? MBio 9:e01923-17. doi: $10.1128 / \mathrm{mBio} .01923-17$

Gutiérrez, D., Hidalgo-Cantabrana, C., Rodríguez, A., García, P., and Ruas-Madiedo, P. (2016). Monitoring in real time the formation and removal of biofilms from clinical related pathogens using an impedance-based technology. PLoS One 11:e0163966. doi: 10.1371/journal.pone.0163966

Gutierrez, D., Rodriguez-Rubio, L., Martinez, B., Rodriguez, A., and Garcia, P. (2016). Bacteriophages as weapons against bacterial biofilms in the food industry. Front. Microbiol. 7:825. doi: 10.3389/fmicb.2016.00825

Gutiérrez, D., Ruas-Madiedo, P., Martínez, B., Rodríguez, A., and García, P. (2014). Effective removal of staphylococcal biofilms by the endolysin LysH5. PLoS One 9:e107307. doi: 10.1371/journal.pone.0107307

Gutiérrez, D., Vandenheuvel, D., Martínez, B., Rodríguez, A., Lavigne, R., and García, P. (2015). Two phages, phiIPLA-RODI and phiIPLA-C1C, lyse monoand dual-species staphylococcal biofilms. Appl. Environ. Microbiol. 81, 3336-3348. doi: 10.1128/AEM.03560-14

Harhala, M., Nelson, D. C., Miernikiewicz, P., Heselpoth, R. D., Brzezicka, B., Majewska, J., et al. (2018). Safety studies of pneumococcal endolysins Cpl-1 and Pal. Viruses 10:E638. doi: 10.3390/v10110638

Hogeveen, H., Huijps, K., and Lam, T. J. (2011). Economic aspects of mastitis: new developments. New Zealand Vet. J. 59, 16-23. doi: 10.1080/ 00480169.2011 .547165

Jun, S. Y., Jang, I. J., Yoon, S., Jang, K., Yu, K. S., Cho, J. Y., et al. (2017). Pharmacokinetics and tolerance of the phage endolysin-based candidate drug SAL200 after a single intravenous administration among healthy volunteers. Antimicrob. Agents Chemother. 61:e02629-16. doi: 10.1128/AAC.02629-16
Jun, S. Y., Jung, G. M., Yoon, S. J., Choi, Y. J., Koh, W. S., Moon, K. S., et al. (2014). Preclinical safety evaluation of intravenously administered SAL200 containing the recombinant phage endolysin SAL-1 as a pharmaceutical ingredient. Antimicrob. Agents Chemother. 58, 2084-2088. doi: 10.1128/AAC.02232-13

Kelley, L. A., Mezulis, S., Yates, C. M., Wass, M. N., and Sternberg, M. J. (2015). The Phyre2 web portal for protein modeling, prediction and analysis. Nat. Protoc. 10, 845-858. doi: 10.1038/nprot.2015.053

Kilkenny, C., Browne, W. J., Cuthill, I. C., Emerson, M., and Altman, D. G. (2010). Improving bioscience research reporting: the ARRIVE guidelines for reporting animal research. PLoS Biol. 8:e1000412. doi: 10.1371/journal. pbio. 1000412

Lambers, H., Piessens, S., Bloem, A., Pronk, H., and Finkel, P. (2006). Natural skin surface $\mathrm{pH}$ is on average below 5 , which is beneficial for its resident flora. Int. J. Cosmet. Sci. 28, 359-370. doi: 10.1111/j.1467-2494.2006.00344.x

Liu, J., Zhang, X., Yang, H., Yuan, J., Wei, H., Yu, J., et al. (2015). Study of the interactions between endolysin and bacterial peptidoglycan on S. aureus by dynamic force spectroscopy. Nanoscale 7, 15245-15250. doi: 10.1039/ C5NR03525B

Martín, V., Maldonado-Barragán, A., Moles, L., Rodríguez-Banos, M., Campo, R. D., Fernández, L., et al. (2012). Sharing of bacterial strains between breast milk and infant feces. J. Hum. Lact. 28, 36-44. doi: 10.1177/0890334411424729

Nyman, A. K., Fasth, C., and Waller, K. P. (2018). Intramammary infections with different non-aureus staphylococci in dairy cows. J. Dairy Sci. 101, 1403-1418. doi: 10.3168/jds.2017-13467

Obeso, J. M., Martinez, B., Rodriguez, A., and Garcia, P. (2008). Lytic activity of the recombinant staphylococcal bacteriophage PhiH5 endolysin active against Staphylococcus aureus in milk. Int. J. Food Microbiol. 128, 212-218. doi: 10.1016/j.ijfoodmicro.2008.08.010

Oliveira, H., Melo, L. D., Santos, S. B., Nobrega, F. L., Ferreira, E. C., Cerca, N., et al. (2013). Molecular aspects and comparative genomics of bacteriophage endolysins. J. Virol. 87, 4558-4570. doi: 10.1128/JVI.03277-12

Otto, M. (2013). Staphylococcal infections: mechanisms of biofilm maturation and detachment as critical determinants of pathogenicity. Annu. Rev. Med. 64, 175-188. doi: 10.1146/annurev-med-042711-140023

Pastagia, M., Euler, C., Chahales, P., Fuentes-Duculan, J., Krueger, J. G., and Fischetti, V. A. (2011). A novel chimeric lysin shows superiority to mupirocin for skin decolonization of methicillin-resistant and -sensitive Staphylococcus aureus strains. Antimicrob. Agents Chemother. 55, 738-744. doi: 10.1128/AAC.00890-10

Paul, V. D., Rajagopalan, S. S., Sundarrajan, S., George, S. E., Asrani, J. Y., Pillai, R., et al. (2011). A novel bacteriophage tail-associated muralytic enzyme (TAME) from phage $\mathrm{K}$ and its development into a potent antistaphylococcal protein. BMC Microbiol. 11:226. doi: 10.1186/1471-2180-11-226

Rehbinder, C., Alenius, S., Bures, J., de las Heras, M. L., Greko, C., Kroon, P. S., et al. (2000). FELASA recommendations for the health monitoring of experimental units of calves, sheep and goats report of the federation of European Laboratory Animal Science Associations (FELASA) working group on animal health. Lab. Anim. 34, 329-350. doi: 10.1258/002367700780387723

Reichelt, P., Schwarz, C., and Donzeau, M. (2006). Single step protocol to purify recombinant proteins with low endotoxin contents. Protein Expr. Purif. 46, 483-488. doi: 10.1016/j.pep.2005.09.027

Rodriguez-Rubio, L., Gutierrez, D., Donovan, D. M., Martinez, B., Rodriguez, A., and Garcia, P. (2016a). Phage lytic proteins: biotechnological applications beyond clinical antimicrobials. Crit. Rev. Biotechnol. 36, 542-552. doi: 10.3109/07388551.2014.993587

Rodriguez-Rubio, L., Chang, W. L., Gutierrez, D., Lavigne, R., Martinez, B., Rodriguez, A., et al. (2016b). 'Artilysation' of endolysin lambdaSa2lys strongly improves its enzymatic and antibacterial activity against streptococci. Sci. Rep. 6:35382. doi: 10.1038/srep35382

Rodriguez-Rubio, L., Martinez, B., Rodriguez, A., Donovan, D. M., and Garcia, P. (2012). Enhanced staphylolytic activity of the Staphylococcus aureus bacteriophage vB_SauS-phiIPLA88 HydH5 virion-associated peptidoglycan hydrolase: fusions, deletions, and synergy with LysH5. Appl. Environ. Microbiol. 78, 2241-2248. doi: 10.1128/AEM.07621-11

Rodríguez, L., Martínez, B., Zhou, Y., Rodríguez, A., Donovan, D. M., and García, P. (2011). Lytic activity of the virion-associated peptidoglycan hydrolase HydH5 of Staphylococcus aureus bacteriophage vB_SauS-phiIPLA88. BMC Microbiol. 11, 138. doi: 10.1186/1471-2180-11-138 
Sass, P., and Bierbaum, G. (2007). Lytic activity of recombinant bacteriophage phil1 and phi12 endolysins on whole cells and biofilms of Staphylococcus aureus. Appl. Environ. Microbiol. 73, 347-352. doi: 10.1128/AEM.01616-06

Schmelcher, M., Donovan, D. M., and Loessner, M. J. (2012a). Bacteriophage endolysins as novel antimicrobials. Future Microbiol. 7, 1147-1171. doi: 10.2217/fmb.12.97

Schmelcher, M., Powell, A. M., Becker, S. C., Camp, M. J., and Donovan, D. M. (2012b). Chimeric phage lysins act synergistically with lysostaphin to kill mastitis-causing Staphylococcus aureus in murine mammary glands. Appl. Environ. Microbiol. 78, 2297-2305. doi: 10.1128/AEM.07050-11

Schmelcher, M., Powell, A. M., Camp, M. J., Pohl, C. S., and Donovan, D. M. (2015a). Synergistic streptococcal phage lambdaSA2 and B30 endolysins kill streptococci in cow milk and in a mouse model of mastitis. Appl. Microbiol. Biotechnol. 99, 8475-8486. doi: 10.1007/s00253-015-6579-0

Schmelcher, M., Shen, Y., Nelson, D. C., Eugster, M. R., Eichenseher, F., Hanke, D. C., et al. (2015b). Evolutionarily distinct bacteriophage endolysins featuring conserved peptidoglycan cleavage sites protect mice from MRSA infection. J. Antimicrob. Chemother. 70, 1453-1465. doi: $10.1093 / \mathrm{jac} / \mathrm{dku} 552$

Schuch, R., Lee, H. M., Schneider, B. C., Sauve, K. L., Law, C., Khan, B. K., et al. (2014). Combination therapy with lysin CF-301 and antibiotic is superior to antibiotic alone for treating methicillin-resistant Staphylococcus aureus-induced murine bacteremia. J. Infect. Dis. 209, 1469-1478. doi: 10.1093/infdis/jit637

Schuch, R., Khan, B. K., Raz, A., Rotolo, J. A., and Wittekind, M. (2017). Bacteriophage yysin CF-301, a potent antistaphylococcal biofilm agent. Antimicrob. Agents Chemother. 61:e02666-16. doi: 10.1128/AAC.02666-16

Valle, J., Toledo-Arana, A., Berasain, C., Ghigo, J. M., Amorena, B., Penades, J. R., et al. (2003). SarA and not sigmaB is essential for biofilm development by Staphylococcus aureus. Mol. Microbiol. 48, 1075-1087. doi: 10.1046/ j.1365-2958.2003.03493.x

Conflict of Interest: The authors declare that the research was conducted in the absence of any commercial or financial relationships that could be construed as a potential conflict of interest.

Copyright (c) 2020 Gutiérrez, Garrido, Fernández, Portilla, Rodríguez, Grilló and García. This is an open-access article distributed under the terms of the Creative Commons Attribution License (CC BY). The use, distribution or reproduction in other forums is permitted, provided the original author(s) and the copyright owner(s) are credited and that the original publication in this journal is cited, in accordance with accepted academic practice. No use, distribution or reproduction is permitted which does not comply with these terms. 